\title{
EXISTENTIALISM: A REACTION TO THE AGE OF ORGANIZATION
}

\author{
James W. Davis, JR. \\ University of Michigan
}

I

N Philosophy for a Time of Crisis Adrienne Koch has called the twentieth century a crisis century and has commented on the extent of the crisis. "It is a crisis of the human person, of the relation of the person to nature, to his work, to other people, to social organization." In another way Hannah Arendt has said the same thing. "It is quite conceivable that the modern age - which began with such an unprecedented and promising outburst of human activity may end in the deadliest, most sterile passivity history has ever known." ${ }^{2}$ To understand why these writers are so pessimistic we have only to look at the social environment people today inhabit. Varied descriptions of this environment could be given, but any description would have to mention the dominance of large-scale organizations. Sheldon Wolin has indeed suggested that today we are in "The Age of Organization." Government is big, business is big, labor is big. Even the student in the university confronts a large impersonal organization.

The age of organization is not altogether a twentieth-century development. The nineteenth had been also a century greatly taken with the idea of organization. Saint-Simon, Wolin notes, "accurately reported on the guiding belief of the organizational age: The superiority of men over other animals 'results directly from a superiority of organization. " " 4 But nineteenth-century interest in organization only foreshadowed increased interest in the twentieth century.

In the twentieth century the fascination with organization reached new heights. Organization was conceived to be the means whereby twentieth-century man transcended his individual limitations. Wealth, power, plenty, and knowledge were all to be had through a kind of social alchemy. But more important, these achievements apparently did not require, as religious transcendence did, a "new man." Man could accomplish great things without himself becoming great, without developing uncommon skills or moral excellence. The secret of organization was that it compensated for human shortcomings. ...

Wolin is by no means alone in commenting on the importance of organization today. Peter Blau has called bureaucracy "the institution that epitomizes the modern era." 6 Because of the importance of bureaucracy many scholars have extensively written about it. Reinhard Bendix, Philip Selznik, and Herbert Simon are among the most well known. Blau's latest book, Formal Organizations, contains a selected bibliography of something over eight hundred items. ${ }^{7}$

Note: This quite brief paper explores nothing in depth. Rather it is a brief survey of a problem that I regard as one of the most pressing (and interesting) of the twentieth century.

${ }^{1}$ Adrienne Koch, Philosophy for a Time of Crisis (New York: Dutton, 1960), p. 22.

${ }^{2}$ Hannah Arendt, The Human Condition (Garden City: Doubleday, 1959), p. 295.

${ }^{3}$ Sheldon S. Wolin, Politics and Vision (Boston: Little, Brown, 1960), p. 352.

${ }^{4}$ Ibid., p. 364 .

slbid., pp. 379-80.

${ }^{6}$ Peter M. Blau, Bureaucracy in Modern Society (New York: Random House, 1956), p. 20.

${ }^{7}$ Peter M. Blau and W. Richard Scott, Formal Organizations (San Francisco: Chandler, 1962). 
The amount of study being devoted to large-scale organizations is indicative of at least two things. First, it indicates most obviously the increasing interest of social scientists in the study of large-scale organizations. And this increased interest is indicative of "the unprecedented growth in modern society of largescale formal organizations. ..."s Study is also being devoted to organizations because scholars are increasingly concerned with their social, moral, and political implications. Exploration of some implications is indeed the purpose of this paper.

Thus far several similar terms have occurred: large-scale organization, formal organization, bureaucracy. The term "complex organization" could also have been used. The most general of these terms is formal organization, the distinctive characteristic of which is that it has been "formally established for the explicit purpose of achieving certain goals." The other terms may apply to formal organizations, organizations varying in size and complexity and degree of bureaucratization. Despite this variance the basic characteristics of formal organizations can be set out: specialization, hierarchy, a system of rules, and impersonality. These characteristics will vary, but in some degree they are present in every formal organization. If we are to understand social life today we must be aware of these characteristics.

If we begin to wonder why the twentieth century is an age of organization we can find many answers. Two writers on administration suggest that the large organization is "a consequence of such factors as demand for higher living standards, technological changes, and the laws of economics." planation. A brief trip into the literature reveals several others. Erich Kahler writes, "The roots of collectivism are to be found in rationalism and technology and not in any specific social or economic doctrine." 11 The philosopher of history, Roderick Seidenberg, has commented on the question at length:

The cumulative drift toward organization in every aspect of modern life is not due to some conscious desire to convert the complexity of society into the likeness of a smooth-functioning machine; it follows, on the contrary, from an inherent necessity, a principle of organization itself, which demands, imperatively and implicitly, an ever increasing extension of organization in the name of its higher functioning and perfected developments. For the principle of organization, as we have seen, carries with it a kind of extroverted necessity to expand; organization breeds organization as a crystal breeds crystal. ${ }^{12}$

\section{Wolin writes:}

Among nineteenth-century writers the idea of organization was partly associated with economic or technological considerations, but in its mature form, such as we know it today, it has meant far more. Organization also signifies a method of social control, a means of imparting order, structure, and regularity to society. ${ }^{13}$

\footnotetext{
${ }^{8}$ Blau, op. cit., p. 5.

Blau and Scott, op. cit., p. 5.

${ }^{10}$ John M. Pfiffner and Frank P. Sherwood, Administrative Organization (Englewood Cliffs: Prentice Hall, 1960), p. 7.

${ }^{11}$ Erich Kahler, The Tower and the Abyss (New York: Braziller, 1957), p. 17. Emphasis is
Kahler's.

${ }^{12}$ Roderick Seidenberg, Posthistoric Man (Boston: Beacon Press, 1957), p. 134.

${ }^{13}$ Wolin, op. cit., p. 364.
} 
Finally we may turn again to Blau who says, "In the large and complex societies of today, the implementation of new social policies requires bureaucratic machinery." 14 He suggests that "the deliberate introduction of a social innovation on a large scale, whether it involves the production of a new weapon or the enforcement of a new law, depends on bureaucratic methods of administration." 15

Each one of these reasons will not be examined. They seem, however, to fall into two groups that might be labeled direct and indirect. Blau in particular and perhaps Pfiffner and Sherwood are getting at the direct causes, the immediate causes. The other writers, perhaps the more philosophically minded, are concerned more with intellectual climatic reasons. The point is that there may be truth in all these explanations, that they are not mutually exclusive. Certainly the complexity of the question suggests that there is no one explanation. In any event the precise reasons for the growth of the age of organization may not be terribly important. It may, indeed, be enough to recognize that vast organizations have developed.

So important is the organization today that Victor Thompson has called modern men "a product of modern organization" ${ }^{16}$ and William $\mathrm{H}$. Whyte has called organization men "the dominant members of our society." ${ }^{17}$ What is an organization man? The definition is hazy, as Whyte admits. In his words, briefly, "The ones I am talking about belong to it [the organization] as well. They are the ones of our middle class who have left home, spiritually as well as physically, to take the vows of organization life, and it is they who are the mind and soul of our great self-perpetuating institutions." 18 Whyte argues in The Organization Man that today a social ethic has replaced the Protestant Ethic. He makes quite clear what he means by social ethic.

By social ethic I mean that contemporary body of thought which makes morally legitimate the pressures of society against the individual. Its major propositions are three: a belief in the group as the source of creativity; a belief in "belongingness" as the ultimate need of the individual; a belief in the application of science to achieve the belongingness. ${ }^{19}$

Kahler, earlier than Whyte, also noted the development of a social ethic, though he did not call it that. He too noted that the group, and not the individual, is the decisive factor. We live, he observed, "in a world in which the collective and no longer the individual is the standard unit." ${ }^{20}$

It should be emphasized that organizations are not only the essence of the present, they may be also the key to the future.

As society is more and more dominated by largeness, bureaucracy's share of total life cannot but grow with it. The future, if there is to be one, points to ever greater hugeness. Beyond that, Boulding is correct in saying, "The electric tabulator, the punched card, operations research

14 Blau, 1956, op. cit., p. 91.

${ }^{15}$ Ibid., p. 92.

${ }^{16}$ Victor A. Thompson, Modern Organization (New York: Knopf, 1961), p. 4.

${ }^{17}$ William H. Whyte, Jr., The Organization Man (Garden City: Doubleday, 1961), p. 3. Emphasis is Whyte's.

${ }^{18}$ Ibid.

${ }^{10}$ Ibid., p. 7.

${ }^{20}$ Kahler, op. cit., p. 226. 
and decision theory all point to still further revolution in the making ..." toward still more bureaucracy. ${ }^{21}$

If it is true that the organizational revolution has not yet reached its zenith then it is all the more important that we attend to it, and to its effects and implications.

\section{II}

In large organizations most people spend most of their time as small cogs in the bureaucratic machinery. And as society itself becomes bureaucratized a man's whole life resembles life in an organization. The organization increasingly becomes the only whole, and each man becomes only a part. The perceived disappearance of man as a whole has had important consequences. Some writers have gone so far as to sugggest that man is being dehumanized. William Barrett suggests that collectivized man is "only an abstract fragment of man." ${ }^{22}$ Kahler suggests that the organization overemphasizes the functional collective part of a person. ${ }^{23}$ And the industrial sociologist Chris Argyris has written: "Most human problems in organizations arise because relatively healthy people in our culture are asked to participate in work situations which coerce them to be dependent, subordinate, submissive and to use few of their more than superficial abilities." ${ }^{24}$

At least in part because of the fragmentation of man induced by large organizations, one of the most common words used in talk about the human situation today is "alienation." With the growth of large-scale organizations and, to be sure, with the increasing pace of urbanization and industrialization, to say nothing of secularization, there has been a loss of community and man has become alienated..5 Modern man's sense of alienation, which would have been great enough because of war, economic crisis, political and religious upheaval, has been intensified by living in the midst of a bureaucratized impersonal society. And if it is not enough to be a stranger to God and to his fellows, man is often also a stranger to himself. "In a society that requires of man only that he perform competently his own particular social function, man becomes identified with this function, and the rest of his being is allowed to subsist as best it can - usually to be dropped below the surface of consciousness and forgotten." ${ }^{26}$

To these events there has been rebellion, both conscious and unconscious. Thompson has commented specifically on what might be called the unconscious rebellion.

There are many people in our society who have not been able to adapt to bureaucracy and who, therefore, find it a constant and complete frustration. Theirs is a kind of social disease which we might call bureausis. "Bureautics" find the rationalism, orderliness, impartiality, and

\footnotetext{
${ }^{21}$ Joseph Bensman and Bernard Rosenberg, "The Meaning of Work in Bureaucratic Society," in Maurice Stein and others, Identity and Anxiety (Glencoe: Free Press, 1960), p. 197.

${ }^{22}$ William Barrett, Irrational Man (Garden City: Doubleday, 1958), p. 26.

${ }^{23}$ Kahler, op. cit., p. 186.

${ }^{24}$ Chris Argyris, "The Individual and Organization: An Empirical Test," Administrative Science Quarterly, 4 (1959), 148.

${ }^{25}$ Koch, op. cit., p. 19.

${ }^{26}$ Barrett, op. cit., p. 31.
} 
impersonality of the bureaucratic organization intolerable. They crave an immediate and tender response to their unique problems, whatever they may be. Bureautics are immature. They have never been weaned from habits of childhood indulgence. ${ }^{27}$

Not everyone, however, views failure to adjust to bureaucracy as evidence of illness. Indeed, even Thompson is not entirely consistent, for elsewhere in his book he remarks, "This denial of adulthood is surely one of the more painful aspects of modern organization." ${ }^{28}$ Thompson, at least, apparently holds the somewhat curious view that if an adult persists in wanting to be an adult he is being immature. Despite this seeming inconsistency Thompson seems to be on the side of adjustment to organization. But there have been voices raised on the other side. The late Robert Lindner, a psychoanalyst, in a popular volume entitled, Must You Conform? answered, "No." Indeed, he suggested that in order to live man must rebel. ${ }^{29}$ The better known work by Whyte amounts to a handbook for anyone who is interested in resisting the organization. The reaction to the age of organization has not been all on the popular, best-seller level, however. There has also been much reaction in more thoughtful, less wellknown circles. This reaction is perhaps epitomized by a current philosophic orientation - existentialism.

\section{III}

What is existentialism? To this question there is no easy answer, there is no short definition. There is not in existentialism a systematic body of thought, nor do existentialists constitute a school. Some thinkers often thought of as existentialists decline the title. Existentialism includes Christians, atheists, and men who can only be placed in between. Above, I suggested that existentialism was more than anything else an orientation, a style of thought, and this perhaps is all that can be said. F. H. Heinemann suggests that existentialism "points to a certain state of mind, to a specific approach or attitude, to a spiritual movement which is of significance in present circumstances and to a specific mode of thought, in any case to something which is alive." ${ }^{30}$ Professor Barrett, in trying to suggest the dimensions of existentialism, says that it

embodies the self questioning of the time, seeking to reorient itself to its own historical destiny. Indeed, the whole problematic of Existentialism unfolds from this historical situation. Alienation and estrangement; a sense of the basic fragility and contingency of human life; the impotence of reason confronted with the depth of existence; the threat of Nothingness, and the solitary and unsheltered condition of the individual before the threat. ${ }^{31}$

In the first section of this paper I suggested that the age of organization had its roots in the nineteenth century. So, too, does existentialism. The century that had Saint-Simon had also Kierkegaard, the champion of the individual. Nietzche and Ibsen were worried also by the encroachment of the organization and were concerned for the individual, the human.

\footnotetext{
${ }^{27}$ Thompson, op. cit., p. 24. Emphasis his.

${ }^{28}$ Ibid., p. 96.

${ }^{29}$ Robert Lindner, Must You Conform? (New York: Rinehart, 1956), p. 176.

${ }^{30}$ F. H. Heinemann, Existentialism and the Modern Predicament (New York: Harper, 1958), p. 165.

${ }^{31}$ Barrett, op. cit., p. 31.
} 
Professor Barrett has suggested that existentialism is "a product of bourgeois society in a state of dissolution." ${ }^{32}$ (Does it have the same roots as Marxism?) Perhaps, it is too much to say that bourgeois society is in a state of dissolution. What is more likely is that dissolution is what the existentialists perceive. For them it is. Existentialism has grown not only from perception and interpretation, however, it has grown also from fact. At least it has grown from fact if alienation, the feeling of estrangement of modern man is taken as fact for the existentialists' point of departure is alienation, "their aim the liberation from estrangement." 33

In fact, the existentialists are philosophers of resistance. They attempt to resist the collectivizing trend, bound up with machine production, which seems to lead in any society ... to depersonalization of man. This resistance takes various forms. Kierkegaard criticizes the modern tendency towards equality and the levelling brought about by public opinion and the rise of the masses. Jaspers protests against the absorption of man by the machinery of the modern welfare state, Marcel against the increased socialization of life, against the extension of the power of the State, and against the substitution of the registration card for the person. ${ }^{34}$

The existentialist sees danger to the life of the individual in the industrial machine, the government bureaucracy, the totalitarian state. But also dangerous are science, morals, laws, Christianity, and humanism. "Faith in science, or reason, or duty, or homo faber, or Christ if it stands between the individual and his total responsibility hides him from himself." ${ }_{35}$ The existentialist accepts in all their fullness the difficulties and dangers of the human situation. He is afraid that anything that will ease our circumstances will also dehumanize us. The existentialist sees that life as a part is easy, but that life as a whole is human and hard.

Above all the existentialist fears rationalism.

... the essence of the existential protest is that rationalism can pervade a whole civilization, to the point where the individuals in that civilization do less and less thinking, and perhaps wind up doing none at all. It can bring this about by dictating the fundamental ways and routines by which life itself moves. Technology is one material incarnation of rationalism, since it derives from science; bureaucracy is another since it aims at the rational control and ordering of social life; and the two-technology and bureaucracy - have come more and more to rule our lives.

But it is not so much rationalism as abstractness that is the existentialists' target; and the abstractness of life in this technological and bureaucratic age is now indeed something to reckon with. $^{36}$

\section{IV}

Enough has by now been said about the existential revolt to the age of organization to let us speculate about its value, its point. To repeat the essentials of what has gone before, existentialism is an attempt to liberate man from the dominance of external forces. It is a resistance movement. In an age of organization it worries about the future of the individual. Because it is almost totally concerned with the individual a viable political or social theory cannot be based

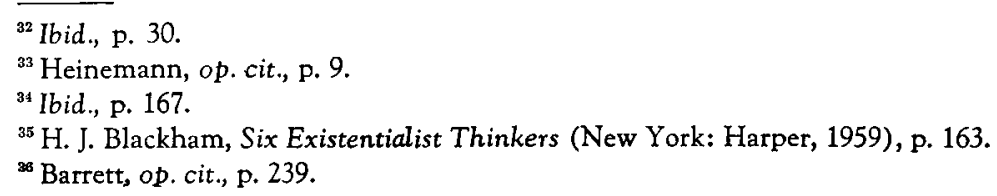


on existentialism. Organization and society are important. We cannot escape technology and bureaucracy. But we must beware of their dominance. Existentialism reminds us of the dangers of organization, technology, rationality, abstraction. These by-words of the modern age are its targets and they are proper targets.

The organization is dangerous. To function it requires submissiveness and conformity, yet these attitudes, if carried over into social and political life, could have unforeseen (and unpleasant) consequences. Submissiveness and conformity are required in a bureaucratic organization for "efficiency." A danger is that the desire for efficiency (achieved by conformity) will carry over to life outside the formal organization. Peter Blau is aware of this danger and says:

... if an association is established for the purpose of deciding upon common goals and courses of action to implement them, which is the function of democratic government..., the free expression of opinion must be safeguarded against other considerations, including those of efficiency. Since bureaucratization prevents the attainment of this objective it must be avoided at all costs. ${ }^{37}$

The danger of bureaucracy is the more great since "the doctrines of democracy and liberalism which underlie our state have made almost no impact upon our bureaucratic organizations." 38

The lack of interest in this liberal tradition seems to be especially pronounced among the more scientifically oriented students of organization. For example, Thibaut and Kelley maintain that it is simpler and more effective to have the same person maintain surveillance and apply sanctions, thereby rejecting the entire historical experience of Western legal institutions. ${ }^{38}$

In the growth of bureaucratic organizations some writers see the doom of democratic institutions. ${ }^{40}$ It would be foolish to deny the danger. The first sentence of this paper noted that the twentieth had been called the crisis century. So long, however, as there are men who insist that man is a whole, and that organization must be only a servant, not a master, then it may not be too dangerous to live in the age of organization.

\footnotetext{
${ }^{37}$ Blau, 1956, op. cit., p. 23.

${ }^{38}$ Thompson, op. cit., p. 65.

${ }^{39} \mathrm{Ibid}$., pp. 65-66, fn. 5 .

${ }^{40}$ Blau, 1956, op. cit., p. 22.
} 